\title{
北伊豆地震 (1930年)による丹那トンネル内地震断層出現状況記録
}

櫻 井 孝*

\section{1. ま えがき}

兵庫県南部地震発生後，国内各地で地震断層，活断層の トレンチ調查が数多く行われている。 トレンチ調査は地表 部に限られるため，これらが地下深所でどのように震源断 層につながっているか興味深い問題である.

1930年11月26日に発生した北伊豆地震では，当時工事中 であった東海道線丹那トンネル内に変位量 $2.1 \mathrm{~m}$ の左横ず れ地震断層が出現した．出現箇所は伊豆半島を南北に走る 「丹那断層」に一致している。 その後, 丹那断層は累積性 の変位地形をむつ活断層であることが明らかにされ1)，卜 レンチ調査 ${ }^{2}$ あ実施されている.

本資料は，当時鉄道省の地質技師であった廣田孝一氏の 坑内観察記録3 した地震断層の状況を紹介するものである。

\section{2. 地震諸元および地表地震断層の概要}

北伊豆地震の諸元は以下のようになっている4). 発 生 日 時: 1930年11月26日 4 時 3 分

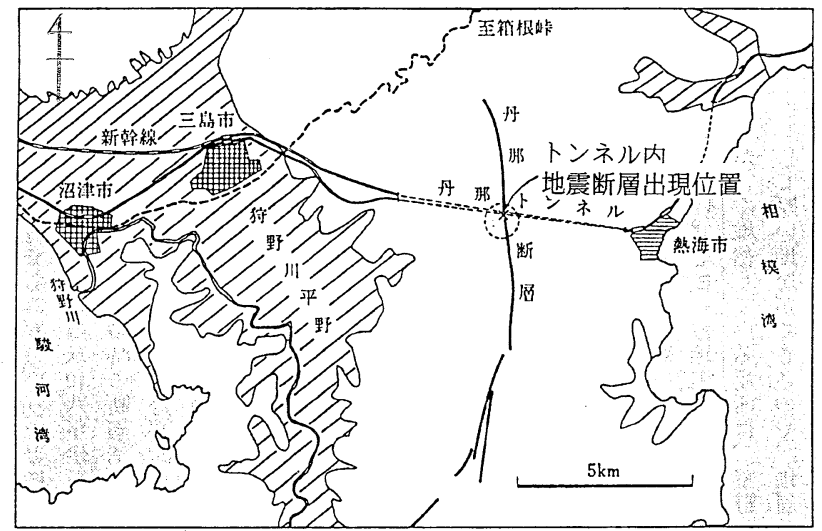

図-1丹那断層に交差する丹那トンネル

* (財)鉄道総合技術研究所 Railway Technical Research Institute(会員)
震源 : 北緯 $35.08^{\circ}$ 東経 $139.05^{\circ}$ 深さ $0 \mathrm{~km}$

マグニチュード : 7.3

地震被害は, 丹那断層上に位置する田代, 丹那の山間盆 地および断層西側の菲山，三島など狩野川下流域で大きく， 震度VIとされている，家屋倒壊率は30～50\%，ところによっ ては80〜90\%となっている. 全壊家屋2,165棟，死者272名 で, 死者の多くは瞬時に家屋が倒壊したことによる圧死亡 されている ${ }^{5)}$. 瞬時に家屋が倒壊したことは，兵庫県南部 地震にもあてはまり，いわゆる直下型地震の特徵といえよ

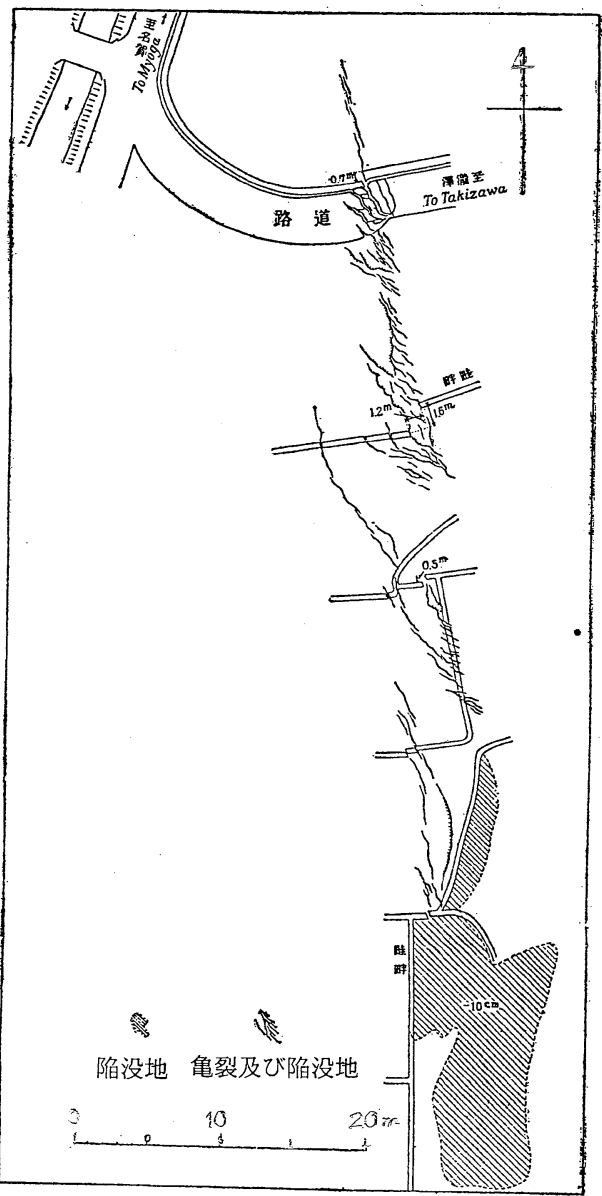

図-2丹那トンネル直上の地震断層出現状況 ${ }^{6}$ 
う.

北伊豆地震により地表に生じた地震断層は, 北は箱根芦 ノ湖から南は修善寺南の姫ノ湯まで延長約 $35 \mathrm{~km}$ にわたっ て扔り, 多くの調查報告がある ${ }^{4 \sim 8)}$. 明瞭な地震断層として, (1)箱根町断層, (2)丹那断層, (3)浮橋断層, (4)大野断層, (5) 加殿断層，(6)姫ノ湯断層の 6 本が出現したとされている ${ }^{4)}$.

丹那盆地周辺の丹那断層と丹那トンネルの位置関係を図 $-1^{7)}$ に示す. 丹那地震断層は田代盆地西縁から丹那盆地南 縁の間でとくに明瞭で, 南北方向の既知の丹那断層に沿っ て出現している. 丹那トンネル直上部付近の地震断層出現 状況を図 $-2^{6}$ に示す. 地上における地震断層の最大変位量 は3.5mで, 鉛直変位は丹那盆地南部を蝶番点としてそれ 以北では東側隆起, 以南で西側隆起, 丹那盆地内は概略水 平となっている5).

\section{3. トンネル内に出現した地震断層}

\section{1 丹那トンネル西口工事の施工状況 ${ }^{9}$}

延長 $7,808 \mathrm{~m}$ の東海道線熱海・函南間丹那トンネル工事 は，1918年に東西両坑口から開始された。そのうち西口か ら東進していた西側の工区は，地震発生時にちょうど丹那 断層破砕帯にさしかかって難渋しており，「西口12,000呎 断層突破工事」と呼ばれていた。土被り $160 \mathrm{~m}$ で那盆地 の真下にあたる。断層破砕帯による大量湧水のため 4 本む の水抜き迁回坑(図-3)が掘削されており，そのうち南側の 水抜き坑 2 つが断層破砕帯中に達していた。図-4 $4^{9}$ に断層 突破後に把握された断層破砕帯分布状況を示す。

西口12,000呎断層突破工事状況を以下に詳述する.

1930年6月21日，本坑導坑より約60m先行していた南側

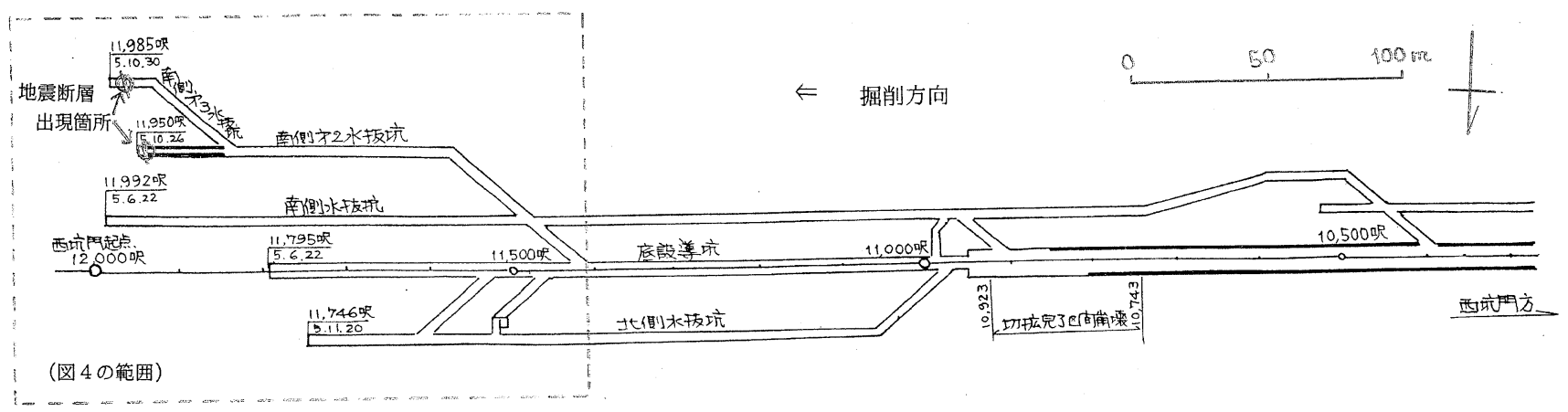

図-3 地震発生時の丹那隧道西口工事掘削状況(丹那隊道工事誌による. 図の右側が西口)

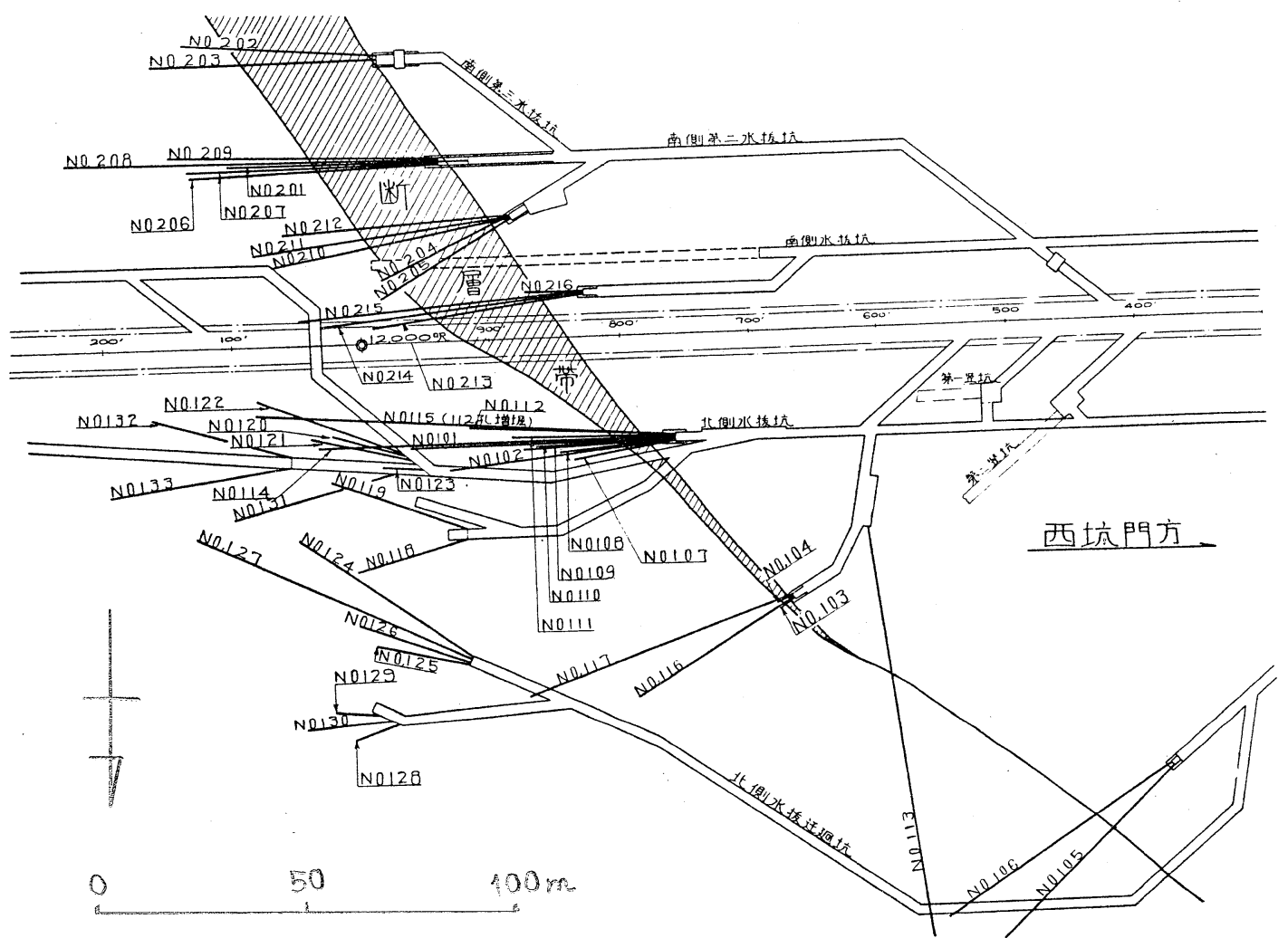

図-4 地震発生約 2 年後の断層帯突破工事状況 


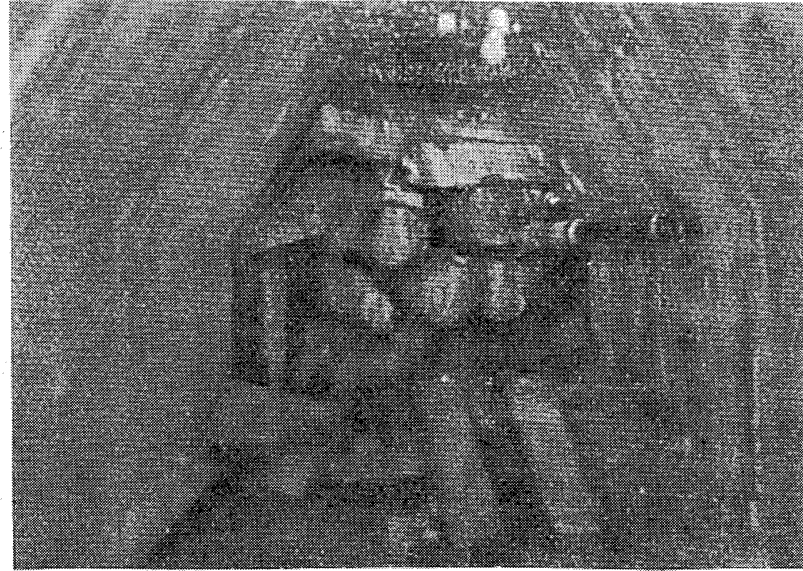

写真-1 西口南側第 2 水抜き坑切羽の松丸太移動状況 ${ }^{9)}$

水抜き坑は, 西口坑口から3,618m(11,871呎)地点から続く 断層破砕帯をほとんど突破しょうとしていた $3,655 \mathrm{~m}$ （11,992呎）地点で大崩壊を起こし, 土砂で埋没した。崩壊 箇所を再度掘削するのは危険であると判断し，南側水抜き 坑加らさらに $24 \mathrm{~m}$ 離して第 2 水抜き坑を掘ることにし， 8 月11日着手した，南側第 2 水抜き坑であ断層破砕帯に入る と非常に大きな側圧を受けて支保工が折損したため, 切羽 の3,642m(11,950呎)地点の手前に松丸太を掘削方向にぎっ しり敷き詰めて山留めし，10月28日さらに南側に第 3 水抜 き坑を掘り進んだ。

南側第 3 水拔き坑が本線と平行になってすぐにこの断層 破砕帯に出会った。 そして $3,653 \mathrm{~m}$ (11,985呎)の切羽地点に おいてパイプによる水拔きのため切羽手前にコンクリート の門を作り終えたのが，地震の前夜，11月25日であった。

\section{2 トンネル切羽の地震断層の状況 ${ }^{3,9}$}

11月26日未明の地震発生により, 南側第 2 水拔き坑の切 羽に充壃しておいた松丸太は断層のずれにより $3,635 \mathrm{~m}$ 地 点で引きずられ, 手前側が $45^{\circ}$ 南に向きを変えていた(写 真 $\left.-\mathbf{1}^{9}\right)$. 一一方, 南側第 3 水抜き坑では $3,651 \mathrm{~m}$ 地点で鋼製 支保工が折損し，坑奥 $2 \mathrm{~m}$ 部分が左側に $2.1 \mathrm{~m}$ 移動し消滅 した。水抜き坑正面にはほぼ水平の条痕(北へ $5^{\circ}$ 傾斜)を つけたきれいな断層鏡面 (写真- $\left.2^{9}\right)$ )が現れた。

廣田 ${ }^{3}$ は地震の約 1 年後, 丸太等を除去した第 2 水抜き 坑で新鮮な断層鏡面を観察し, その走向傾斜を $\mathrm{N} 22^{\circ} \mathrm{W} 78^{\circ}$ $\mathrm{W}$ と测定している。 また，丹那隧道工事誌9)でもトンネル 直交方向(招打む称南北方向)加 $30^{\circ}$ 程度の角度をむって 図示している，以上より，丹那断層の全体的な走向である 南北方向に対し, トンネル内に現れた断層面はこれに $20^{\circ}$ 程度斜交していたと判断される。

さらに廣田 ${ }^{3)}$ は, 地震後に掘進した北側水抜き坑には, 南側第 2 , 第 3 水抜き坑の断層鏡面(走向はお打む龵 $\mathrm{N} 20^{\circ}$ W)の延長は現れなかったと報告している。 また，工事関 係者はトンネル工事での遭遇状況から，断層破砕帯の形状 を図-5のような平面図に模式化している ${ }^{9)}$.

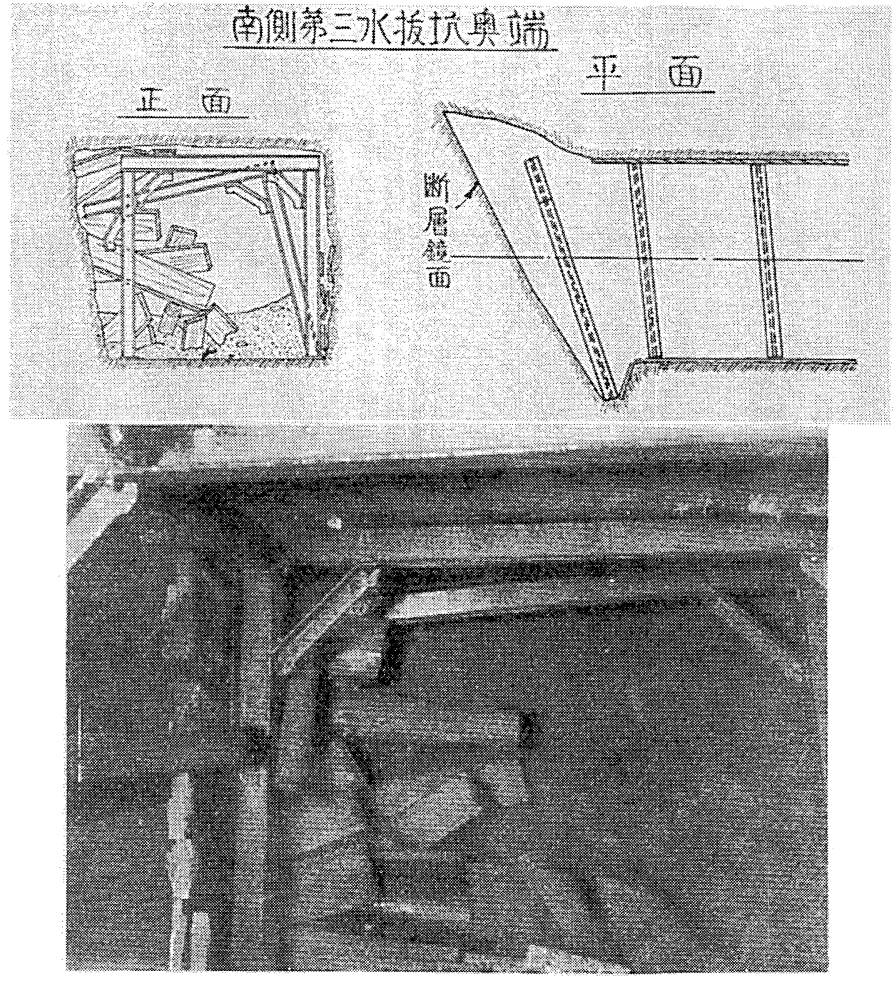

写真-2 西口南側第 3 水抜き坑切羽に出現した断層鏡面 ${ }^{9}$

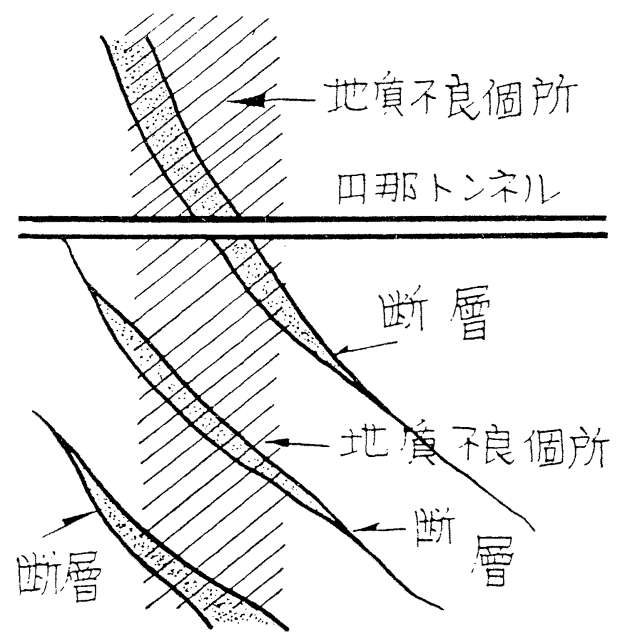

図-5 当時の「断層」と「地質不良箇所」の考え方 ${ }^{92}$

また，上述したように，第 3 水抜坑の変位量 $2.1 \mathrm{~m}$ の断 層面の走向は, 南北方向の丹那断層本体の走向之異なって いるため, 地震時トンネル内に出現した断層面は, 左横ず れ断層運動に伴う「リーデルせん断の鏡面」であると考え られる。

\section{3 断層鏡面の観察記録 ${ }^{3)}$}

以下に，廣田 ${ }^{3)}$ による断層鏡面(南側第 2 , 第 3 水抜き坑 のいずれか不明)の観察結果の記載を引用する.

「断層鏡面は暗茶褐色粘土で，よく締まっている，条痕 の方向は北へ $2^{\circ}$ 傾斜している. 面上の無数の条痕は爪で 傷つけた位の太さのむのが多く, $3 \mathrm{~mm} く$ らいの間隔で一面 


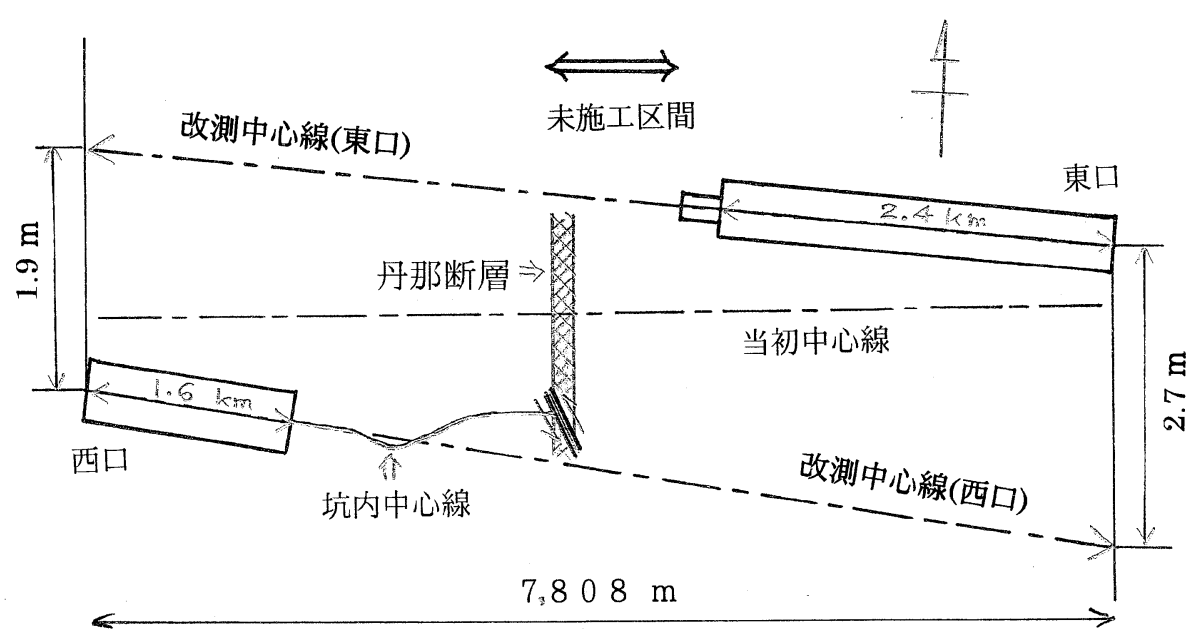

図-6 断層変位によるトンネル中心線測量結果(鉄道省部内資料より作成)

に引かれている。その間に3〜9m拉き位に鉛筆の芯の太さ の条痕がある。これらは概して凹形であるが，そのうちの 相当数は凸形を示している. 条痕の長いものは左から右に ほとんど全部続いているが, 条痕の大部分は中断している. この方向のものが最も多く，最も長い．しかし全部が幾何 学的平行線をなしている訳ではなく，ある部分は平行をな し，ある部分は $3 \sim 5^{\circ}$ 北側に下がっている。まれに， $18^{\circ}$ 南下がりのものもある。 また，部分的に波形をしているも のもある.」

また，地震断層の運動を次のように解釈している.

「条痕が多様であり，また中途で切れたりしていること は，断層面の砂質粘土に含まれる多量の断層角砶の大小各 粒が，断層の移動に際し相手の断層面を引っかきつつ，自 分自身あ転々としていたものと思われる。しかも不規則な 例外方向の条痕は一般方向の条痕に覆われていることから， 断層の動き始めには角礫は回転しながら妙な動きをするが， 全体的移動の後半もしくは大半では角礫は自転することを やめたために，断層本来の動きが最後の一般方向を示され たこととなり，結局断層の動きは南に向かって $2^{\circ}$ 上がり （著者注；「北へ向かって2下がり」とは書かれていない） の定まった方向への直線運動をなしたものと考えられる.」

\section{4 丹那トンネル中心線の変位状況}

地震後の中心線測量は, 中心線の直線性が保たれていた 西口 $1.6 \mathrm{~km}$ およ゙東口 $2.4 \mathrm{~km}$ 間の覆工完了区間の中心線を 用いて行われた。 それぞれの中心線を延長すると, 図-6の ように西口からの延長線は $2.7 \mathrm{~m}$ 南側へ, 東口の延長線は 1.9 $\mathrm{m}$ 北側へずれている。地震前の当初の中心線は一本の直線 であったと見なされるため，このずれ量の差 $0.8 \mathrm{~m}$ は左横 ずれ断層を境に，その両側に時計回りの回転運動があり， 見かけ上西側の回転量が大きかったことを示している.

なお，東口と西口の坑口間の地上における水準測量結果 は, 西口方が相対的に $12 \mathrm{~cm}$ 下がっているとしている ${ }^{9}$.

\section{4. ま と め}

（1）北伊豆地震時に工事中であった丹那トンネル西口工事 南側水抜き坑切羽付近 (土被り $160 \mathrm{~m}$ ) に地震断層が出現し た．地震断層の走向は，南北方向とされる丹那断層に対し 西側へ $20^{\circ}$ 程度斜交している.

（2）この地震断層(鏡面)は，走向や連続性から主たる地震 断層のリーデルせん断と解釈できる.

\section{5.あと がき}

地震断層の左ずれに伴う丹那トンネルの平面線形の変更 は，東西両坑口に近い被害のなかった本覆工部分の直線を 生かし，断層を挟んだ本線未施工部分に半径 $4,000 \mathrm{~m}$ の カーブを入れて修正している。 また，東口側が相対的に隆 起したのに合わせて未施工部分の勾配变更も行ってい $る^{9)}$.

新幹線丹那トンネルは戦時中の弾丸列車構想時にルート が決められた。その決定にあたっては北伊豆地震の経験を 踏まえた議論がなされた，鉄道省部内資料によると「軟弱 地盤(丹那盆地を念頭においている)を避ける，山の尾根へ 入れる，断層の少ない箇所を選ぶ」といったルート選定方 針が立てられた。しかし，「複数の候補ルートの優劣につ いて，地震に対しては確実な判断は下しえない」とし，地 質が十分確認されている，トンネル延長が短いという2つ の理由で，旧トンネルに沿う現ルート（東海道新幹線新丹 那トンネル)が決定された。

本稿をまとめるにあたり (財)鉄道総合技術研究所・小野

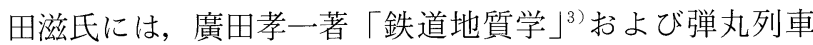
構想時の鉄道省部内資料を紹介していただいた。 また，査 読者の一人からは重要な指摘および貴重な資料を提供いた だいた。記して感謝します。 


\section{引用 文 献}

1）久野久(1936)：最近の地質時代における丹那断層の運動につ いて, 地理学評論, 12-1, pp.18-32.

2) 第 3 次丹那断層発掘調査研究グループ (1988)：1985年丹那断 層(丹那・子乃神地区) トレンチ調査, 活断層研究, 5 , pp.4249

3）廣田孝一(1941）: 鉄道地質学, 鉄道工学社, pp.111-116

4）宇佐美龍夫 (1987) : 新編日本被害地震総覧, 東京大学出版会, pp.184-188,

5）金子史朗(1979）: 活断層一地震の謎をさぐる，講談社現代新
書548, pp.8-35.

6）井原敬之助・石井清彦 (1932）：北伊豆震災地調査報文，地質 調查所, 地質調查所報告第112号, pp.73-98.

7）松田時彦(1972)：1930年北伊豆地震の地震断層, 伊豆半島, 東海大学出版会, pp.73-93.

8) 柴正博(1996)：丹那断層の地震断層としての実態, 大震災, 東海大学出版会, pp.229-243.

9）鉄道省熱海建設事務所 (1936)：丹那隧道工事誌，鉄道省, pp.421-432.

Jour. Japan Soc. Eng. Geol., Vol.39, No.6, pp.540-544, 1999

A Report on the Earthquake Fault Appearing in the Tanna Tunnel under Construction by North-Izu Earthquake 1930

Takashi SAKURAI 